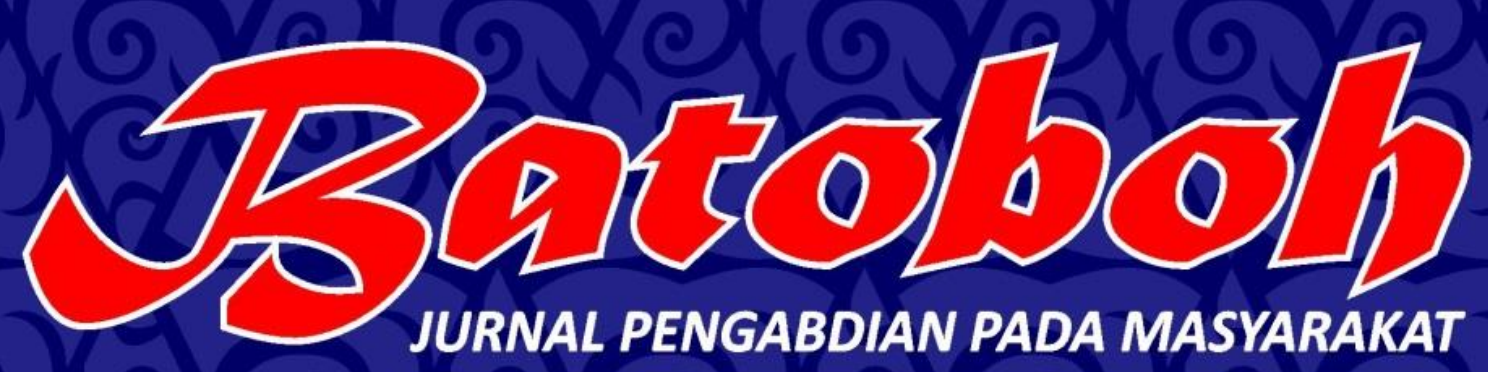

ISSN: 2548-5458

Volume 1

Nomor 2

JURNAL PENGABDIAN PADA MASYARAKAT

Oktober 2016

hlm. 131-266

Yusfil, Zulkifli, Erlinda

PENERAPAN TEKNOLOGI SENI PADA SANGGAR SENI TRADISIONAL

DI KABUPATEN PESISIR SELATAN SUMATERA BARAT

Asril

PELATIHAN LAGU SIONTONG TABANG, KURETA MANDAKI, DAN OYAK TABUIK

PADA GRUP GANDANG TASA ANAK-ANAK, SANGGAR ANAK NAGARI DESA SUNGAI PASAK, KOTA PARIAMAN

Nofrial, Wahyono, Riski Rahmat Kurniawan Dan Alek Hengki Ziora

PEMANFAATAN SERBUK GERGAJI MENJADI PRODUK KERAJINAN DI WAN PERABOT,

TARANTANG KECAMATAN HARAU, 50 KOTA

Dira Herawati, Muhammad Husni, A Nick Koto Agam, Eza Ramadhani

PELATIHAN FOTOGRAFI PADA KEGIATAN EKSTRA KURIKULER DI SMKN 2 PADANGPANJANG

F. X Yatno Karyadi, Eriswan, Bari, Rahmat, Irham

PELATIHAN PEMBUATAN VIDEO DAN FOTO MAKRO MENGGUNAKAN TABLE-TOP STUDIO UNTUK SISWA SMA

Novina Yetri Fatrina, Ediantes, Putri Andam Dewi, Suri Handai Yani

PELATIHAN TEKNIK MEMBUAT RIAS EFEK UNTUK FILM FIKSI PADA SMK 2 PADANGPANJANG

Rosta Minawati, Heri Sasongko, Gilang Febriano, Vini Rusmana

PENGENALAN PRODUKSI FILM DOKUMENTER BAGI SISWA/ SISWI SEKOLAH MENEGAH ATAS

Hafif HR, Fahmi Marh, Ade Sulistiawan, Dino Ashari

PENERAPAN MULTI DISIPLIN SENI DALAM KEGIATAN DRUMBAND PADA EKSTRAKURIKULER SMA 3 PADANGPANJANG

Febri Yulika, Selvi kasman, Putri Khairina Masta

PENINGKATAN KOMPETENSI GURU MELALUI PELATIHAN PENULISAN KARYA TULIS ILMIAH

Darmansyah, Novesar Jamarun, Firdaus, Indra Arifin, Fitra Muhaddis

PELATIHAN INSTRUMEN MUSIK TRADISIONAL MINANGKABAU DI MAN 2 GUNUNG PADANGPANJANG 



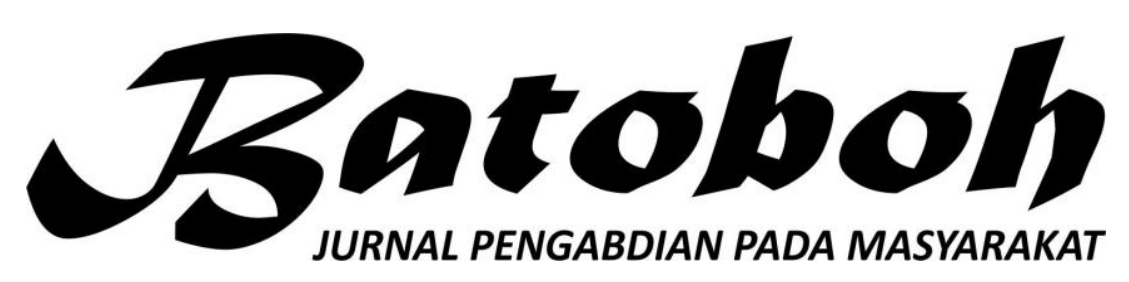

ISSN: 2548-5458 Volume 1, Nomor 2, Oktober 2016, hlm. 131-266

Terbit dua kali setahun pada bulan April dan Oktober. Pengelola Jumal Pengabdian pada Masyarakat merupakan subsistem LPPMPP Institut Seni Indonesia (ISI) Padangpanjang.

\author{
Pengarah \\ Rektor ISIPadangpanjang \\ Penanggung Jawab \\ Kepala Pusat Penerbitan ISI Padangpanjang \\ KetuaPenyunting \\ Andar Indra Sastra \\ Penyunting \\ Asril \\ Sahrul \\ RostaMinawati \\ Harissman \\ Pimpinan Redaksi \\ Saaduddin \\ Redaktur \\ Liza Asriana \\ Rori Dolayance \\ Tata Letak dan Desain Sampul \\ Yoni Sudiani \\ WebJurnal \\ Thegar Risky
}

Alamat Pengelola Jumal Batoboh:LPPMPP ISI Padangpanjang

Jalan Bahder Johan Padangpanjang 27128, Sumatera Barat; Telepon (0752) 82077 Fax. 82803;

e-mail; batoboh@gmail.com

Catatan. Isi/Materi jurnal adalah tanggung jawab Penulis.

Diterbitkan Oleh

Institut Seni Indonesia (ISI) Padangpanjang 


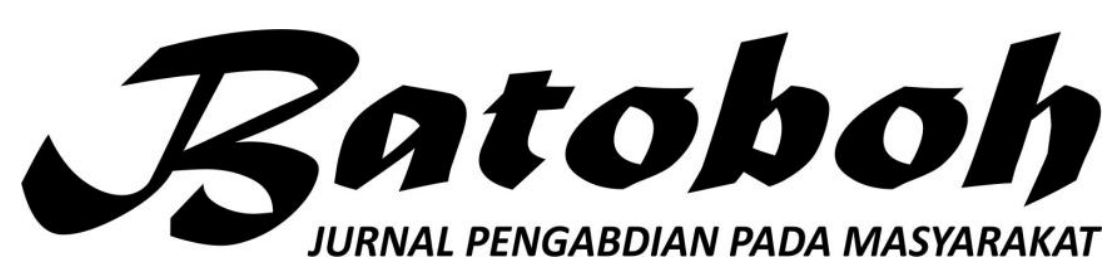

ISSN: 2548-5458 Volume 1, Nomor 2, Oktober 2016, hlm. 131-266

\section{DAFTAR ISI}

\begin{tabular}{|l|l|}
\hline \multicolumn{1}{|c|}{ PENULIS } & \multicolumn{1}{c}{ JUDUL } \\
\hline Yusfil, Zulkifli, Erlinda & $\begin{array}{l}\text { Penerapan Teknologi Seni Pada Sanggar Seni } \\
\text { Tradisional Di Kabupaten Pesisir Selatan Sumatera } \\
\text { Barat }\end{array}$ \\
Asril & $\begin{array}{l}\text { Pelatihan Lagu Siontong Tabang, Kureta Mandaki, } \\
\text { Dan Oyak Tabuik Pada Grup Gandang Tasa Anak- } \\
\text { Anak, Sanggar Anak Nagari Desa Sungai Pasak, } \\
\text { Kota Pariaman }\end{array}$ \\
$\begin{array}{l}\text { Nofrial, Wahyono, Riski } \\
\text { Rahmat Kurniawan Dan } \\
\text { Alek Hengki Ziora }\end{array}$ & $\begin{array}{l}\text { Pemanfaatan Serbuk Gergaji Menjadi Produk } \\
\text { Kerajinan Di Wan Perabot, Tarantang Kecamatan } \\
\text { Harau, 50 Kota }\end{array}$ \\
\hline
\end{tabular}

HALAMAN

Dira Herawati,

Muhammad Husni, A

Nick Koto Agam, Eza

Ramadhani

F. X Yatno Karyadi,

Pelatihan Fotografi Pada Kegiatan Ekstra

Kurikuler Di SMKN 2 Padangpanjang

131-144

$145-164$

Eriswan, Bari, Rahmat, Irham

Novina Yetri Fatrina, Ediantes, Putri Andam Dewi, Suri Handai Yani

Pelatihan Pembuatan Video Dan Foto Makro

190-200 Menggunakan Table-Top Studio Untuk Siswa SMA

Pelatihan Teknik Membuat Rias Efek Untuk Film 201-212 Fiksi Pada SMK 2 Padangpanjang

Rosta Minawati, Heri Sasongko, Gilang

Pengenalan Produksi Film Dokumenter Bagi $213-227$ Febriano, Vini Rusmana

Hafif HR, Fahmi Marh, Ade Sulistiawan, Dino Ashari Siswa/Siswi Sekolah Menegah Atas

$165-181$ 182-189

Febri Yulika, Selvi Kasman, Putri Khairina Masta

Darmansyah, Novesar Jamarun, Firdaus' Indra Arifin, Fitra Muhaddis

Penerapan Multi Disiplin Seni Dalam Kegiatan Drumband Pada Ekstrakurikuler SMA 3 Padangpanjang

Peningkatan Kompetensi Guru Melalui Pelatihan Penulisan Karya Tulis Ilmiah

Pelatihan Instrumen Musik Tradisional $256-266$ Minangkabau Di MAN 2 Gunung Padangpanjang

\footnotetext{
Peraturan Direktur Jenderal Pendidikan Tinggi Kementerian Pendidikan Kebudayaan Republik Indonesia Nomor 1 Tahun 2014 Tanggal Tentang Pedoman Akreditasi Terbitan Berkala Ilmiah. Jumal Batoboh Terbitan Vol. 1, April dan Oktober 2016 Memakaikan Pedoman Akreditasi Berkala Ilmiah Tersebut.
} 



\title{
PELATIHAN INSTRUMEN MUSIK TRADISIONAL MINANGKABAU DI MAN 2 GUNUNG PADANGPANJANG
}

\author{
Darmansyah, Novesar Jamarun, Firdaus' Indra Arifin, Fitra Muhaddis \\ Prodi Seni Karawitan \\ Prodi Fotografi \\ Prodi Seni Teater \\ Fakultas Seni Pertunjukan-ISI Padangpanjang \\ Jl. Bahder Djohan-Padangpanjang-Sumatera Barat \\ novesar62@yahoo.com \\ firdausasdar@rocketmail.com
}

\begin{abstract}
ABSTRAK
Kesenian tradisional berfungsi memperkuat kebudayaan nasional dan memperkuat identitas bangsa. Agar kesenian tradisional bisa bertahan dari perkembangan zaman, maka diperlukan alih generasi. Salah satu bentuk alih generasi adalah pelatihan alat musik tradisi dilingkungan sekolahmenengah MAN 2 Gunung Padangpanjang.Kegiatan alih generasi kesenian tradisi dilakukan dalam kegiatan ekstra kurikuler kesenian disekolah tersebut.

Permasalahan yang diangkat adalah kurangnya literatur kesenian tradisi dan terbatasnya tenaga pelatih yang dibutuhkan dalam kegiatan ekstra kurikuler kesenian disekolah menengah. Metode pelatihan yang dipakai adalah menggunakan metode imited singing yaitu melatih dengan mencontohkan langsung cara memainkan alat musik tradisi, dan siswa menirukannya.

Melalui pelatihan ini diharapkan siswa-siswa sekolah menengah mengenal kesenian tradisional, dapat memainkan alat musik tradisi, sehingga dapat menumbuhkan rasa suka dan meningkatkan kepedulian siswa-siswa pada kesenian tradisi sebagai milik mereka yang harus dijaga dan dipertahankan.
\end{abstract}

Kata kunci; kesenian tradisional,pelatihan alat musik tradisi. 


\section{PENDAHULUAN}

Pertunjukan

\section{kesenian}

kesenian tradisional secara teori tradisional sebagai salah satu unsur budaya daerah yang menjadi bagian budaya nasional yang harus dipertahankan keberadaaannya dan untuk mata pelajaran lainnya. harus tetap dapat dirasakan nilai-nilai ketradisiannya. Kesenian tradisional membutuhkan kepedulian dari masyarakat pendukungnya terutama generasi muda. Tidak hanya itu, kesenian tradisi membutuhkan kepedulian dari berbagai pihak agar dapat terlibat menjaga kelestariannya. ISI Padangpanjang sebagai lembaga tinggi seni ikut bertanggung jawab untuk mengajarkan pada generasi selanjutnya.

Institut Seni Indonesia (ISI) sebagai lembaga pendidikan tinggi mempunyai andil besar dalam proses alih generasi kesenia tradisional pada generasi muda, terutama pada institusi pendidikan sekolah dasar sampai sekolah menengah. Jika diamati dan dibuat perbandingan muatan kurikulum di sekolah- sekolah, terutama pada sekolah menengah maka dapat dilihat bahwa kandungan materi pada mata pelajaran seni budaya belum cukup porsinya untuk materi yang membahas ini adalah untuk meningkatkan

Permasalahan diatas menjadi salah satu faktor yang menjadikan kesenian tradisional hanya punya kesempatan sedikit untuk diperkenalkan pada generasi muda. Permasalahan lainnya yang juga besar pengaruhnya terhadap keberadaan kesenian tradisi adalah perkembangan kesenian budaya lain terutama budaya populer dan budaya barat yang lebih bersifat komersil. Kesenian yang datang kemudian ini cepat dikomsumsi oleh generasi muda. Budaya baru lebih mudah disukai dan ditiru terutama oleh generasi muda sekarang ini. Berkurangnya ketidak pedulian generasi penerus tidak dapat kita bebankan kesalahan itu semua pada mereka, Sebagai pendidik para guru juga memiliki tanggung jawab memberikan materi yang ada kaitannnya dengan seni budaya untuk menambah wawasan para siswa dan memberikan motivasi pada mereka. Hal 
apresiasi mereka terhadap seni budaya secara umum dan kesenian tradisi secara khusus.

Dalam kurikulum mata pelajaran sekolah menengah ada mata pelajaran seni budaya, tetapi materi dalam mata pelajaran tersebut digabung dengan materi seni yang lainnya, seperti seni rupa, seni tari, seni kriya, dan seni musik. Akibatnya untuk kesenian tradisi hanya memdapat porsi yang sedikit sesuai dengan presentase yang sudah ditetapkan dalam kurikulum.

Berawal dari kondisi ini dan sebagai salah satu bentuk kepedulian dari pihak sekolah untuk menyikapinya maka materi kesenian tradisional dimasukkan pada kegiatan ekstra kurikuler kesenian disekolah. Kegiatan ini merupakan salah satu cara untuk memperkenalkan lebih banyak lagi berbagai literatur kesenian tradisional.Akibatnya yang diharapkan meningkatkan pemahaman, pengetahuan para generasi muda tentang kesenian tradisional. Pada kegiatan ekstra kurikuler para siswa tidak hanya sekedar diberi pengetahuan sebatas teori saja, tetapi mereka diperkenalkan langsung dan diajarkan memainkan instrumen tradisional tersebut.Sesuai dengan pendapat (Rohidi, 2000), bahwa kesenian milik bersama dari suatu masyarakat karena mencerminkan pengetahuan dan system nilainya. Sekolah merupakan sebuah institusi yang bertujuan mencerdaskan masyarakatnya. Sehingga dapat dijadikan salah satu tempat yang akan mewadahi proses pelestarian kesenian tradisi pada generasi penerus.

Salah satu sekolah menengah yang menjalankan fungsinya yang ikut terlibat langsung pada proses regenerasi kesenian tradisi dan menjadikan kesenian tradisional sebagai materi pada kegiatan ekstra kurikuler kesenian disekolah menengah adalah Madrasah Aliyah Negeri 2 Gunung padang panjang. Bentuk pelatihan yang dilakukan adalah alat musik tradisi minangkabau untuk para siswa siswanya, meliputi pelatihan alat musik talempong, bansi, sarunai dan gendang. Keterbatasan sumber daya manusia yang ada disekolah, menjadi kendala bagi pihak sekolah untuk melaksanakan kegiatan tersebut.Sekolah membutuhkan tenaga pelatih yang memiliki kompetensi sebagai seniman akademisi makauntuk 
berjalannya kegiatan ekstra kurikuler dan menjadi kekuatan dalam kesenian disekolah MAN 2 kebudayaan nasional Indonesia.

Padangpanjang dapat, maka sekolah bekerja sama dengan perguruan seni yang ada diwilayah setempat.

A. Hasil dan Pembahasan

Keterlibatan perguruan seni ISI Kesenian tradisi di Sumatera padangpanjang terkait pelestarian Barat tumbuh dan berkembang kesenian tradisi adalah dalam bentuk ditengah masyarakat pendukungnya bantuan tenaga pelatih karawitan (Etnis Minangkabau). Ia menyatu minangkabau untuk membantu melatih dengan beragam kesenian yang terdiri memainkan alat musik tradisi pada dari tarian, nyanyian, sastra daerah, dan kegiatan ekstra kurikuler di sekolah. didukung oleh alat musik tradisi yang Diharapkan dengan keterlibatan beragam, yang terdapat dihampir seluruh wilayah Minangkabau, yang institusi pendidikan dalam melestarikan melambangkan identitas dan ciri khas kesenian tradisi, maka akan dapat suatu daerah tersebut. Keberadaan membantu memperkenalkan kesenian kesenian tradisi Minangkabau dari tradisi pada siswa-siswa.Mengajarkan setiap periode waktu mengalami cara memainkan alat musik perubahan dan perkembangan sesuai tradisisehingga akan berdampak pada dengan perubahan dan perkembangan tumbuhnya kepedulian dan rasa masyarakat pendukungnya. (sukerta, memiliki terhadap kesenian tradisi pada 2011, p. 1).

diri siswa-siswa tersebut. Sebagai Banyak faktor yang generasi muda, mereka adalah bagian mempengaruhi perkembangan atau dari masyarakat yang juga harus ikut perubahan suatu kesenian tradisional, bertanggung jawab sebagai anak bangsa diantaranya teknologi, ekonomi, yang harus mempertahankan maupun sosial. Seiring dengan keberadaan kesenian tradisional sebagai perkembangan masyarakat harta kekayaan bangsa yang tidak pendukungnya, kesenian tradisi dimiliki oleh Negara lain. Sebagai mengalami perkembangan yang tidak budaya daerah yang menjadi identitas terlalu signifikan. Perkembangan yang terjadi pada kesenian tradisi tidak 
seimbang dengan perkembangan masyarakat pendukungnya disemua sektor diatas.Kesenian tradisi seakanakan ada kecendrungan semakin tidak berkembang. Walaupun ada perkambangan tapi cenderung sangat lambat, bahkan hanya berjalan ditempat. Kondisi yang terjadi pada saat sekarang ini adalah perkembangan kesenian tradisi yang sudah mengalami perubahan akibat kreatifitas seniman pelakunya dan akibat tuntutan kebutuhan perkembangan masyarakat. Misalnya seni budaya yang menjadi salah satu asset dalam pariwisata budaya, dalam hal ini kesenian tradisi sebagai salah satu materi yang dijual untuk kepentingan industri pariwisata sudah dirubah sedemikian rupa sesuai dengan tuntutan pasar.Sehingga nilainilai ketradisiannya berkurang, bahkan hilang sama sekali. Generasi muda sekarang lebih banyak mengkonsumsi adalah kesenian tradisi yang sudah mengalami perubahan.Sehingga sulit membedakan mana kesenian tradisi yang masih asli atau yang sudah mengalami perubahan.

Sebagai suatu seni pertunjukan, kesenian tradisi juga didukung oleh unsur-unsur yang mendukungnya.Kata seni pertunjukan mengandung pengertian untuk mempertunjukan sesuatu yang bernilai seni dansenantiasa menarik perhatian bila ditonton. M. Jazuli (dikutip dalam Dyah, 2013: 25) menjelaskan bahwa kepuasan bagi seorang penikmat seni pertunjukan tergantung sejauh mana aspek jiwa melibatkan diri didalam pertunjukan itu dan kesan yang diperoleh setelah menikmati, sehingga menimbulkan adanya perubahan dalam diri sendiri, seperti memperoleh wawasan baru, pengalaman baru, dan kedalaman atau kepekaan dalam menangkap sesuatu sehingga bermakna. Dapat dilihat bahwa aspek penikmat seni sangat mempengaruhi eksistensi sebuah kesenian khususnya tradisional. Kesenian, dalam pertunjukannya selalu didukung atau dilengkapi oleh alat musik tradisi seperti talempong, sarunai, bansi, dan gendang. Semua unsur tesebut apabila tidak didukung oleh masyarakat pendukungnya, Maka keberadaannya tidak akan bertahan lama dilingkungan masyarakat tersebut.

Salah satu bentuk kepedulian masyarakat pendukung sebuah kesenian tradisi adalah ikut serta membantu agar 
eksistensi keseniantradisis tetap dapat bertahan. Ikut memperkenalkan kesenian tradisi pada para generasi muda dan memfasilitasi mereka untuk mempelajarinya. Kegiatan ini dilakukan oleh pihak sekolah menengah melalui kegiatan ekstra kurikuler dibidang kesenian. Dalam kegiatan ekstra kurikuler diperkenalkan alat musik tradisi yang dipergunakan dalam kesenian tradisi tersebut, serta sekaligus diajarkan cara memainkan alat musik tradisi tersebut.

Alat musik tradisi yang diajarkan pada siswa sekolah menengah tersebut adalah sejenis alat musik pukul terbuat dari logam kuningan yang dikenal di Minangkabau sebagai Talempong. Jika diklasifikasi kan maka talempong tergolong instrument musik jenis idiophone. Dalam terminologi musik hal ini berarti alat musik yang sumber bunyinya berasal dari alat musik itu sendiri (Banoe, 2003: 191). Keberadaan talempong sangat familiar dan identik dengan masyarakat Minangkabau pada umumnya. Dalam pelatihan talempong di sekolah menengah yang diperkenalkan adalah talempong pacik dan talempong duduak. Talempong pacik merupakan

telempong yang dalam petunjukannya dimainkan dengan cara dipegang.Teknik permainan talempong pacik dimainkan dengan system interlocking (saling mengisi), dengan beberapa talempong lainnya. Dalam sebuah pertunjukan talempong pacik dimainkan oleh tiga orang pemain.

Talempong duduak, dimainkan biasanya berfungsi untuk melodis, talempong duduk diletakkan pada dua buah tali yang direntangkan sejajar pada standar kayu serta dimainkan secara horizontal.Talempong duduak yang dikenal pada saat sekarang adalah talempong yang memiliki sistim tangga nada diatonik, serta diamainkan oleh satu orang saja sebagai pemain melodi pokok.Talempong yang diperkenalkan dan diajarkan pada siswa sekolah menengah adalah talempong yang menggunakan nada diatonis.Hal ini untuk memudahkan memberi pemahaman dan mengajarkan alat musik tradisi ini pada siswa sekolah menengah.

Pelatihan alat musik tradisi
yang diberikan untuk siswa sekolah
menengah tidak hanya instrumen
talempong saja tetapi juga ditambah
dengan alat musik tradisi lainnya


seperti; alat tiup bansi dan sarunai, serta gendang sebagai alat musik tradisi yang berfungsi sebagai alat musik yang memainkan pola ritme (ritmis). Bansi dan sarunai merupakan alat musik tiup tradisi yang terbuat dari bambu kecil dan tipis (talang, saruiak) yang diberi beberapa lobang sebagai penghasil bunyi dan dimainkan dengan cara ditiup, panjangnya kira-kira $30 \mathrm{~cm}$ sampai dengan $35 \mathrm{~cm}$ dengan diameter kira-kira $3 \mathrm{~cm}$. Bansi dan sarunai dibuat dengan mengunakan sistim tangga nada diatonis dan dipergunakan sebagai alat musik tradisi yang membawakan melodi.

Dalam pelatihan memainkan alat musik tradisi dikegiatan ekstra kurikuler sekolah menengah MAN 2 Gunuang Padangpanjang, semua intrumen diatas diajarkan secara bertahap satu persatu pada setiap siswa yang terlibat dalam kegiatan ekstra kurikuler dengan tahapan proses latihan sebagai berikut;

Tahap awal; pada tahap ini yang paling penting dilakukan adalah memotivasi para siswa bahwa mempelajari alat musik tradisi itu menarik dan menyenangkan serta tidak sulit.Para siswa juga diberi pemahaman bahwa mereka sebagai generasi muda bertanggung jawab untuk melestarikan kesenian tradisi milik daerah kita, dan tidak harus mempunyai rasa malu atau enggan mempelajarinya.

Setelah pemahaman para siswa sama pada kesenian tradisi daerah, pelatihan baru memasuki tahapan berikutnya yaitu memberi pemahaman dan pengetahuan tentang alat musik tradisi Minangkabau dengan beberapa jenis instrument musik yang akan dan dapat mereka pelajari dikegiatan ekstra kurikuler. Para siswa juga diberi gambaran kegiatan latihan yaitu tentang proses latihan yang akan mereka lakukan dan tentang materi yang akan mereka pelajari, serta lagu yang akan dimainkan dengan menggunakan alat musik tradisi yaitu lagu Kambie Rajo dan Tigo Duo.

Tahap kedua; sebelum proses latihan dimulai terlebih dahulu pelatih membagi siswa berdasarkan keinginan dan kemampuan musikalitasnya untuk nanti pada masing-masing siswa ditentukan akan memainkan instrument alat tradisi apa.Selanjutnya pelatih dan para siswa menyepakati jadwal latihan yang akan dilakukan dalam beberapa kali latihan. 
Tahap ketiga; proses latihan talempong.Memainkan melodi lagu dimulai dengan mengajarkan teknik pada instrument talempong dilakukan memainkan talempong pada seluruh oleh siswa secara bergantian sehingga siswa, metode yang digunakan adalah mereka bisa saling mendengarkan dan metode meniru (immited singing). mengoreksi permainan yang dilakukan Pelatih mencontohkan langsung cara oleh teman-temannya. memegang stik (pemukul) talempong, Setelah siswa dapat memainkan dan cara memainkan instrument melodi tersebut, maka pelatih talempong dengan menggunakan stik, memberikan materi lanjutan tentang materi ini dilakukan sambil cara memainkan melodi dengan menerangkan nada-nada yang menggunakan tanda dinamik, yaitu dihasilkan oleh alat musik tradisi tanda musik tentang keras dan lunaknya talempong.Tahap berikutnya para siswa cara memainkan melodi yang mencoba memainkan talempong sesuai membantu siswa memainkan melodi dengan arahan pelatih. dengan hasil bunyi yang enak didengar

Setelah melalui tahap awal dan siswa sudah menguasai materi tentang telinga (merdu). Pelatih juga mencontohkan memainkan melodi teknik memainkan talempong, pelatih dengan menggunakan tanda dinamik, akan mengajarkan materi baru, yaitu baru setelah itu para siswa berlatih mengajarkan melodi yang akan memainkan melodi menggunakan tanda dimainkan dengan instrument dinamik.

talempong. Materi lagu ini merupakan Tahap keempat adalah ketika rangkaian melodi yang akan dibawakan beberapa siswa melatih materi untuk dengan talempong sebagai instrument instrumen talempong, maka pelatih pembawa melodi pokok. Materi lagu melanjutkan memberi materi latihan diajarkan dan dicontohkan secara untuk para siswa yang akan memainkan bertahap, pertama para siswa harus instrument tiup bansi dan sarunai.Pada mempelajari melodi lagunya dan tahap ini pelatih juga mencontohkan menghafalkan melodi tersebut sampai cara memainkan alat tiup bansi dan benar-benar hafal dan seterusnya baru sarunai serta bagaimana teknik meniup di aplikasikan pada instrument yang benar.Teknik penjarian yang tepat 
agar menghasilkan bunyi yang diharapkan.Selanjutnya para siswa berlatih memainkan instrument bansi dan sarunai. Setelah siswa mampu meniup dengan benar dan sudah menguasai teknik penjarian, maka pada tahapan berikutnya pelatih akan mengajarkan materi melodi lagu yang akan dimainkan menggunakan alat tiup bansi dan sarunai. Sama dengan melodi talempong, melodi alat tiup bansi dan sarunai juga harus dihafal oleh siswa terlebih dahulu, dan pada tahapan ini pelatih mencontohkan teknik penjarian pada alat tiup untuk melodi yang sudah dikuasai siswa. Baru pada tahapan selanjutnya melodi tersebut dimainkan dengan instrumen bansi dan sarunai, siswa mempelajari memainkan melodi lagu pada instrument tiup bansi dan sarunai sampai lancar.

Tahap kelima; pelatih mencontohkan cara memainkan alat musik tradisi ritmis yaitu gendang. Sebagai alat pukul, gendang dimainkan menggunakan tangan atau menggunakan stik dengan pola ritme tertentu.Selain cara memainkan siswa juga diajarkan berbagai pola pukulan yang biasa dipergunakan dalam memainkan instrument gendang.
Selanjutnya para siswa berlatih memainkan instrument gendang dengan pola pukulan yang bervariasi.

Tahap keenam; setelah masingmasing siswa menguasai dan mampu memainkan instrument masing-masing dengan benar maka pelatih akan menggabungkan semua siswa untuk dapat bermain secara bersama dengan instrument yang berbeda-beda. Proses penggabungan semua instrument tidak dapat begitu saja dilakukan oleh para siswa, terlebih dahulu pelatih memberi pemahaman bagaimana cara bermain bersama. Menginformasikan hal-hal yang harus diperhatikan dalam bermain musik bersama, secara teori para siswa harus paham pada saat bermain bersama mereka tidak boleh egois ingin lebih menonjolkan kelebihan masingmasing. Tetapi prinsip bermain bersama adalah menghasilkan sebuah permainan musik yang seimbang, yang setiap pemainnya harus mampu bekerja sama sengan pemain lainnya.

Tahapan terakhir yang harus dilakukan oleh pelatih adalah mengoreksi hasil latihan yang dilakukan oleh masing-masing siswa. Membetulkan kekeliruan teknik bermain alat musik yang dilakukan oleh 
siswa. Mendengarkan keluhan-keluhan para siswa tentang kesulitan mereka mempelajari alat musik tradisi, Memahami aspirasi mereka terkait kesenian tradisional. Materi yang sudah dikusai oleh para siswa akan ditampilkan pada acara pentas seni yang diadakan disekolah. Maka pelatih akan mempersiapkan materi yang dimainkan oleh siswa agar layak untuk ditampilkan. Pelatih memberi pemahaman pada siswa tentang sebuah pertunjukan, prinsip-prinsip pertunjukkan serta hal-hal lainnya yang harus dipersiapkan oleh siswa antara lain; property kelengkapan sebuah pertunjukan, seperti kostum dan yang lainnya.

\section{Keberhasilan} sebuah pertunjukan kesenian tradisi menjadi barometer keberhasilan pelatih dalam melatih siswa sekolah menengah, serta kita menjadi tahu dan memahami sejauh mana apresiasi para siswa tentang kesenian tradisi.

\section{B. Target Capaian.}

Hasil yang dicapai dalam pelatihan alat musik tradisional adalah para siswa memahami bagaimana kesenian tradisional itu dan lebih mengenal alat musik tradisi dengan segala keunikannya, dengan mempelajari alat musik tradisi akan menumbuhkan rasa kepedulian dan rasa suka terhadap alat musik tradisi. Program pengabdian berupa latihan alat musik tradisi akan berdampak terhadap perkembangan dan eksistensi kesenian tradisi itu sendiri untuk tetap dapat bertahan ditengah kesenian lainnya yang juga berkembang ditengah masyarakat pada saat sekarang ini.

\section{KESIMPULAN}

Kegiatan pelatihan instrument musik tradisional Minangkabau di MAN 2 Gunung Padangpanjang adalah memperkenalkan alat musik tradisi Minangkabau pada generasi muda.Meningkatkan apresiasi siswa sekolah menengah atas terhadap kesenian tradisional.Menumbuhkan rasa peduli para siswa terhadap seni budaya daerah mereka. Terjalinnya kerja sama pihak sekolah dengan pihak perguruan tinggi terkait pelestarian seni budaya daerah Minangkabau.

Untuk kesenian tradisi kegiatan pelatihan ini bermanfaat sebagai salah satu cara untuk tetap dapat dikenal oleh masyarakat pendukungnya agar mampu 
bertahan ditengah perkembangan zaman dimana ada kecendrungan kesenian tradisi mulai ditinggalkan oleh masyarakat pendukungnya.Kegiatan pelatihan instrument musik tradisi memberi pemahaman kepada kita sebagai masyarakat, bahwa kita tidak boleh membiarkan kesenian tradisi hilang begitu saja.Sebagai masyarakat pendukung kita berkewajiban ikut terlibat langsung atau secara tidak langsung berkewajiban melestarikan kesenian tradisi.

\section{KEPUSTAKAAN}

A.A. Navis. (1984). Alam Takambang Jadi Guru: Adat dan Kebudayaan Minangkabau. Jakarta:Graffiti press

Banoe, Pono. (2003). Kamus Musik, Yogyakarta, Kanisius.

Budhidharma, Pra. (2001). Seri Pustaka Musik Farabi, Buku Kerja Teori Musik : Sebagai

Pengantar Komposisi dan Arransemen. Jakarta, PT Elex Media Komputindo Gramedia.

Dieter mach 1994, Ilmu Melodi, Pusat Musik Liturgi, Yogyakarta.

Hanefi, Ediwar, Hajijar .(2004). Talempong Minangkabau (buku I). Bandung, Universitas Pendidikan Indonesia (P4ST UPI).
Indra Sastra, A (2011). Ensambel Talempong Jinjiang Minangkabau Dalam Persfekti Sejarah.

Diperoleh 16 maret 2015 dari http:/musikminangkabau.Lo gspot.com/

Made Sukerta, p.(2011). Metode Penyusunan Karya Musik (sebuah

Alternatif).Surakarta, ISI Press Solo.

Syailendra.(2009). Instrumen Musik Minangkabau dalam Kajian Organologis. Jurnal Bahasa

dan Seni vol.10 no.1, Universitas Negeri Padang.

Umar Kayam, (1991), Seni, Tradisi Masyarakat. PT. Sinar Harapan, Jakarta 
FILOSOFI "BATOBOH": Dalam masyarakat Minangkabau upacara-upacara yang dilakukan sebelum mendirikan bangunan baik Rumah Gadang maupun Balairung (Balai Adat) serta bangunan lainnya yang dikenal dengan beberapa upacara yang disebut dengan batoboh. Batoboh berasal dari kata Taboh yang artinya menebang atau mengambil sesuatu, jadi dengan mengambil kayu dihutan sebagai bahan utama dalam membangun rumah dan bangunan lainnya. Upacara Batoboh ini sangat bermanfaat bagi masyarakat Minangkabau yaitu dapat meningkatkan Gotong-Royong dan solidaritas antar sesama suku Minangkabau karena memberi kesempatan kepada kerabat-kerabat untuk terlibat dalam pembangunan rumah serta bangunan lain.

Alamat Redaksi: LPPMPP ISI Padangpanjang Jalan Bahder Johan Padangpanjang 27128 Sumatera Barat Telp. (0752) 485466, Fax.(0752) 82803 e-mail: batoboh@gmail.com

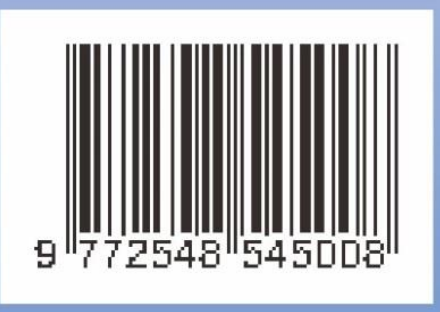

